\title{
THE DEVELOPMENT OF SOCIAL POLICY, 1800-1945"
}

Bernard Harris, School of Social Work and Social Policy, Faculty of Humanities and Social Sciences, University of Strathclyde, 141 St James' Road, Glasgow G4 OLT. Email: bernard.harris@strath.ac.uk.

\section{ISSUES IN FOCUS}

The period between 1800 and 1945 saw many changes in welfare policy. At the start of this period, most people relied on their families and local communities for support in times of need, and central government played very little role in the provision of welfare services. However, by 1945 the state played a much larger role in the provision of a wide range of services, covering all the main areas of social policy. This chapter provides an introduction to the development of public welfare policy during this period by examining the following issues:

- The initial growth of state welfare intervention before circa 1870 .

- Changing attitudes to welfare provision between 1870 and 1900 .

- The Liberal welfare reforms of 1906-14.

- The development of social policy between 1914 and 1939.

- The impact of the Second World War on the development of the 'welfare state'.

\section{The development of social policy and the 'mixed economy of welfare'}

During the last thirty years, the historiography of British welfare provision has been transformed by a growing emphasis on the provision of welfare outside the state.

This paper has been prepared for the Hugh Bochel and Guy Daly, eds. Social policy, Harlow: Pearson, $4^{\text {th }}$ edition.

Forthcoming in H. Bochel and G. Daly, eds., Social policy, London: Routledge, $4^{\text {th }}$ edition. 
In 1994, Geoffrey Finlayson (1994: 6), argued that Britain had always 'possessed what is now called a "mixed economy of welfare"' and that 'within that mixed economy, the state was only one element - and, arguably, for much of the nineteenth century, and even the twentieth century, it was not the most important element'. Other historians have echoed this view. Jane Lewis (1995: 3) claimed that Britain has 'always ... had a mixed economy of welfare, in which the state, the voluntary sector, the family and the market have played different parts at different points in time' and Joanna Innes (1996: 140) concluded that 'a mixed economy of welfare' persisted throughout western Europe from the sixteenth century onwards (see also Harris and Bridgen 2007).

However, it is also important to recognise the extent to which the state's role within this mixed economy has developed and expanded since the end of the eighteenth century. At the beginning of this period, the majority of people relied on their families and their local communities for welfare support, and central government played a very limited role in the provision of welfare services (Brewer 1989: 40). Over the course of next 150 years, the extent of state intervention increased dramatically. It included the introduction of measures to regulate conditions of work and establish minimum standards for the construction of new housing, as well as the provision of public services (such as public health and education) and the introduction of new forms of income support, such as unemployment insurance and health insurance. These developments meant that, despite their deficiencies, Britain still possessed a more comprehensive set of social services than almost any other democratic country on the eve of the Second World War (Stevenson and Cook 1994: 83).

This chapter presents an overview of the growth of state welfare provision between circa 1800 and 1945 . The next section summarises the main developments in social policy during the first seven decades of the nineteenth edition. 
century, including changes in the methods of poor relief and the development of attempts to regulate living and working conditions, the history of public educational provision, and the introduction of public health reforms. Section three explores the various changes which occurred in the provision of poor relief between 1870 and 1906 , together with new developments in the history of public health and housing and the acceptance of state responsibility for the provision of elementary education under the Forster Education Act of 1870 and the Education (Scotland) Act of 1872 . The fourth section examines the history of the 'Liberal welfare reforms' of 1906-11, including the introduction of school meals and school medical inspection, old-age pensions, the Housing and Town Planning Act, a radical set of tax reforms, and the creation of statutory health and unemployment insurance schemes. Section five explores the development of welfare provision in interwar Britain, including the expansion of both the extent and the coverage of the unemployment insurance scheme, the introduction of a contributory pension scheme for those between the ages of sixty-five and seventy, the changing nature of poor relief (or public assistance, as it became known), the reform of hospital services, the introduction of subsidised forms of council housing, and the partial reorganisation of the education system. The final section discusses the history of social policy during the Second World War, and the impact of these changes on the development of welfare provision after 1945.

One of the ways in which we can 'measure' the growth of public welfare provision is by looking at the statistics of public expenditure. During the nineteenth century, the majority of the additional expenditure on social services was incurred by local authorities (Szreter 2002a: 29), but in the twentieth century a much larger share of the burden was borne by central government (see Table 1). In 1790 , central government expenditure on social services probably amounted to no more than one per cent of the country's total national income, but this proportion 
more than doubled between 1790 and 1900 , and by 1938 it had reached 10.7 per cent, before increasing still further after the Second World War. This expenditure reflected a degree of public intervention in welfare provision which would have been almost unthinkable at the end of the eighteenth century.

Table 1. Government expenditure on social, economic and environmental services in the United Kingdom, 1790-2000.

\begin{tabular}{ccccc} 
& \multicolumn{2}{c}{ As \% of total expenditure } & \multicolumn{2}{c}{ As \% of GDP } \\
\hline & $\begin{array}{c}\text { Social } \\
\text { services }\end{array}$ & $\begin{array}{c}\text { Economic and } \\
\text { environmental } \\
\text { services }\end{array}$ & $\begin{array}{c}\text { Social } \\
\text { services }\end{array}$ & $\begin{array}{c}\text { Economic and } \\
\text { environmental } \\
\text { services }\end{array}$ \\
\hline 1790 & 8.7 & 8.7 & 1.0 & 1.0 \\
1840 & 9.4 & 9.4 & 1.0 & 1.0 \\
1890 & 20.9 & 14.8 & 1.9 & 1.3 \\
1900 & 18.0 & 17.3 & 2.5 & 2.4 \\
1910 & 32.8 & 19.2 & 4.0 & 2.3 \\
1920 & 25.9 & 14.4 & 6.9 & 3.8 \\
1930 & 42.3 & 14.9 & 10.3 & 3.6 \\
1938 & 37.6 & 12.7 & 10.7 & 3.6 \\
1950 & 41.9 & 15.7 & 14.1 & 5.3 \\
1960 & 46.1 & 15.1 & 16.9 & 5.5 \\
1970 & 47.1 & 25.5 & 20.0 & 10.8 \\
1980 & 54.3 & 16.2 & 25.4 & 7.6 \\
1990 & 55.0 & 12.5 & 21.9 & 5.0 \\
$2000 A$ & 60.3 & 9.8 & 22.9 & 3.7 \\
$2000 B$ & 64.3 & 7.9 & 23.7 & 2.9 \\
2010 & 66.1 & 7.5 & 31.1 & 3.5 \\
\hline
\end{tabular}

Notes. The table includes two different sets of estimates for 2000 . These reflect differences in the methods used to generate the figures on which the two sets are based.

Sources: See Harris 2004: 12-13; Harris 2014: 142.

The years between 1800 and 1945 were also characterised by some important changes in methods of taxation. At the start of the eighteenth century, the government obtained the majority of its income from indirect taxes in the form of customs and excise duties, supplemented by smaller amounts of income from direct taxes on land and other forms of assessable wealth and stamp duties, but in 1799 William Pitt the Younger introduced the first income tax. This was originally 
intended as a means of raising emergency revenue for the Napoleonic War and it was abandoned during the Peace of Amiens in 1802-3 and again following the end of the war in 1816, before being reintroduced by Robert Peel in 1842 . Peel believed that income tax could provide an alternative to more traditional forms of taxation but the Liberal government of 1906-11 decided to expand the scope of the income tax system as part of its plans for funding increases in welfare spending. This was one of the main reasons why the percentage of total revenue derived from income tax rose from 13.5 per cent in the final quarter of the nineteenth century to 37.5 per cent in the second quarter of the twentieth century (see Figure 1).

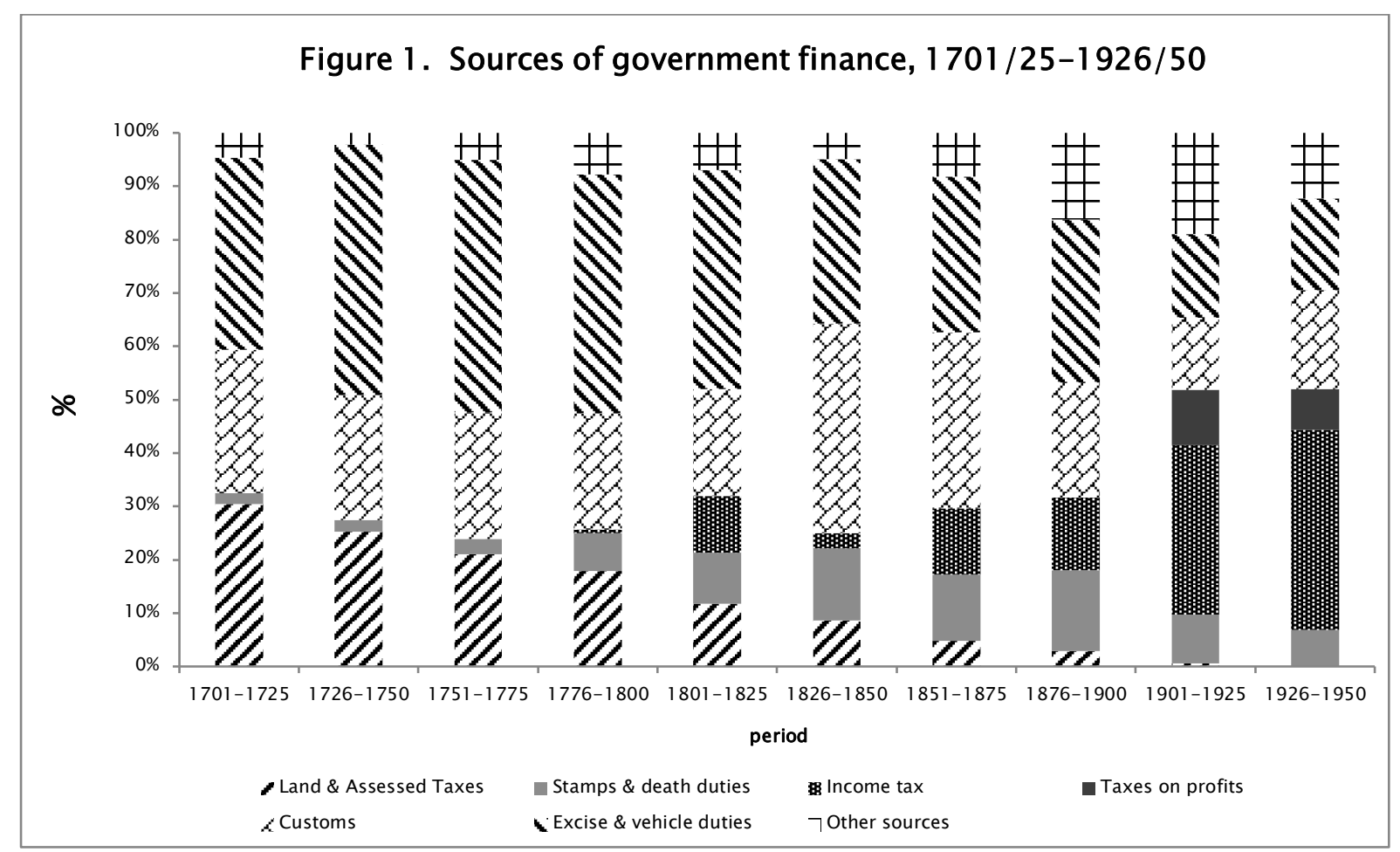

Source: Harris 2004: 10.

\section{Victorian origins of the welfare state}

Although it is conventional to assume that the 'welfare state' only came into being in Britain after 1945, some historians have argued that a form of welfare state 
existed much earlier. Paul Slack (1999: 164-5) claimed that England already possessed a 'local welfare state' by the end of the eighteenth century, and David Roberts (1960: 315) suggested that the foundations of a national welfare state were laid between 1833 and 1854, but other historians have rejected this view. Ursula Henriques (1979: 268) argued that it was difficult to apply the label 'Victorian origins of the welfare state' to the mid-nineteenth century when 'the welfare state represents, at least in theory, the total reversal of nineteenth-century attitudes', and Pat Thane (1982: vii; 1996: xii) claimed that it was only around 1870 'that important demands began to arise for the state ... to take a permanent, as distinct from a temporary and residual, responsibility for the social and economic conditions experienced by its citizens'. However, despite these reservations, the period between 1800 and 1870 witnessed a number of developments which had profound implications for the role of the state in the provision of welfare services. These developments were particularly apparent in relation to the administration of the Poor Law, and to the identification of the state's responsibility for the promotion of education and the protection of public health.

One of the main challenges posed by this chapter is the need to recognise the existence of different welfare traditions, and different systems of education and health administration, in different parts of the United Kingdom. This is particularly true of the history of poor relief. In both Ireland and Scotland, the provision of poor relief was largely dependent on voluntary arrangements before the 1830s (Luddy 1998: 149-50; Mitchison 2000: 1). However, in England and Wales, the Poor Law Acts of 1597 and 1601 had conferred a legal obligation on the churchwardens of every parish to 'set the poor on work', make arrangements for the apprenticeship of pauper children and maintain those who were unable to work. The creation of this system led the French writer, Alexis de Tocqueville, to observe in 1835 that England was 'the only country in Europe which has systematised and applied the theories of 
public charity on a large scale'. He also claimed that this was one of the main reasons why, in his view, the level of indigence was much greater than elsewhere (Harris 2004: 40-1).

During the eighteenth century, the estimated cost of this system rose from just under two shillings (ten pence) per head in 1696 to nearly nine shillings (45 pence) in 1802/3 (Kidd 1999: 168). This increase fuelled a growing debate about the provision of poor relief which culminated in the passage of the Poor Law Amendment Act in 1834 . This Act aimed to curtail the welfare entitlements of ablebodied men by requiring them to enter a workhouse, or submit to some other form of deterrent test, in order to qualify for relief, and it led to a sharp reduction in the number of able-bodied men who featured on the relief rolls (Williams 1981: 59-60; Harris 2004: 40-53). However, it also witnessed some important changes in the administrative structure of the poor law, including the reorganisation of individual parishes into Poor Law Unions, the establishment of the central Poor Law Commission, and the appointment of Assistant Commissioners who were then able to exercise a significant influence over the development of local relief policies (Harling 1992). Even though these measures were originally designed to prevent the growth of welfare expenditure, they also reflected the view that there ought to be a nationally-agreed framework for the possession of welfare rights which could be applied across the entire country. 
Thought provoker: The Poor Law Amendment Act has been described as 'one of the great watersheds in English social policy' (Jones 1990: 13). One of its main aims was to establish a framework for the introduction of policies which would lead to a dramatic reduction in poor law expenditure. However, when the Poor Law Commissioners tried to introduce the new Act in the north of England, they encountered opposition from members of both the working and middle classes (Rose 1966; Edsall 1971). Why might middle-class ratepayers have been opposed to the changes the Commissioners wished to introduce?

The 1830 s and 1840 s also saw the extension of the poor law to Ireland and changes in the Scottish system of poor relief. Although Ireland was generally regarded as possessing a great deal of poverty, it lacked any form of statutory poor relief before the 1830s. In 1833, the Government appointed a Royal Commission to investigate the extent of poverty and the best ways of responding to it. The Royal Commission advocated a wide range of measures, including a state-subsidised emigration scheme; land-drainage and reclamation; a comprehensive system of agricultural education; a public works programme; and the development of institutional provision for the disabled poor, but its recommendations were rejected (Ó Tuathaigh 1972: 111-2). In 1838, the Government decided to impose a new system, in which all relief would provided inside a workhouse. However, this restriction was removed following the outbreak of the Irish Potato Famine and the passage of the Irish Poor Relief Extension Act in 1847 (Considine and Dukelow 2009: 101-3).

The introduction of a new system of poor relief in Scotland followed a rather different path. Although it is conventional to date the origins of the Scottish Poor Law to the Poor Law Acts of 1574 and 1579, most poor relief was provided through 
voluntary agencies and there was no right to support for the able-bodied. However, these arrangements came under growing pressure during the 1830 s and 1840 s and a new Act was passed in 1845 . The Act established a new body - the Board of Supervision - to oversee the administration of poor relief across Scotland and required every burghal parish or group of parishes to appoint a Parochial Board of Managers of the Poor to administer the poor law locally. It also confirmed the right of every parish to levy a local tax, or assessment, to pay for poor relief. However, although the Act sought to encourage individual parishes to form larger groups, or Combinations, this aim was largely unsuccessful, and the established principle that 'nothing herein contained shall ... confer a right to demand relief on able-bodied persons out of employment' was reaffirmed (Harris 2019: 42).

The first half of the nineteenth century also witnessed a number of other developments. In 1802, Parliament passed the Health and Morals of Apprentices Act, which sought to limit the working hours of apprentices and prevent them from working through the night, and this was followed by a series of other measures, including the Factory Acts of 1819, 1825 and 1833 (Harris 2004: 34-5). The Government established a Board of Commissioners for National Education in Ireland in 1831 (Considine and Dukelow 2009: 7), and the first state grant for public education in England, Scotland and Wales was introduced in 1833. Even though the value of the grant was very small (only $£ 20,000$ ), both the extent and the scope of education grants increased significantly in the ensuing years. In 1839 Parliament established a Privy Council Committee on Education to supervise the expenditure of public funds, and after 1843 schools were permitted to request public support for the purchase of new equipment as well as the construction of new buildings (Harris 2004: 35).

Important as these developments were, it is arguable that the most important example of the growth of state intervention in this period lay in the sphere of public edition. 
health. During the course of the eighteenth century, Britain had witnessed a sharp reduction in the incidence of what demographers call 'crisis mortality' (i.e. years in which mortality rates are exceptionally high) and there was a gradual improvement in the underlying rate of mortality between circa 1780 and 1820 , but these developments were placed in jeopardy by the rapid growth of large towns and cities (Fogel 1994: 370-1; Flinn 1965: 13). At the beginning of the nineteenth century, it has been estimated that just over one-third of the total population of England and Wales lived in towns or cities containing more than 2,500 inhabitants, and there was only one city - London - whose population exceeded one hundred thousand. However, over the course of the next fifty years, the number of 'large' towns and cities increased to ten, and the proportion of the total population which was classified as 'urban' increased to 54 per cent (Harris 2004: 30). These changes were seen to represent a major threat to the overall standard of public health because the death rates experienced by people living in large and rapidly-growing towns were significantly higher than those experienced elsewhere (Szreter and Mooney 1998).

The threat which the growth of large towns posed to the health of the population was one of the major causes which lay behind the development of the campaign for public health reform between 1800 and 1850 , culminating in the passage of the first Public Health Act in 1848. This Act led to the creation of the first central government health department - the General Board of Health - and granted it the power to conduct its own investigations into the sanitary condition of areas where more than ten per cent of ratepayers requested such an enquiry, or where the local death rate had exceeded 23 deaths per thousand living over a seven year period. However, the Act only applied to England and Wales and, although it was undoubtedly a major watershed in the history of social policy, its practical significance can easily be exaggerated. In the five years after the Act came into 
operation, the initiation of enquiries by the General Board of Health led to the establishment of local Boards of Health in fourteen areas where the local death rate had exceeded 23 deaths per thousand and 168 areas where an enquiry had been requested by local ratepayers, but the combined population of these areas accounted for less than one-eighth of the total population of England and Wales at the time of the 1851 census (Harris 2004: 109-10).

\section{Welfare provision 1870-1906}

As the previous section has demonstrated, the period between 1800 and 1870 witnessed a number of important changes in the role played by the state in the establishment of minimum standards and the development of welfare services, but there were still major gaps in the development of public welfare provision and this is why Pat Thane argued that it was only after 1870 that the state came under concerted pressure 'to take a permanent ... responsibility for the social and economic conditions ... [of] its citizens' (1982: vii; 1996: xii). Although some commentators were calling for the introduction of tighter controls on the distribution of poor relief, others were advocating an enhanced role for the state in the improvement of housing standards and the provision of health and education services, and these demands exerted a major impact on the development of social policy between 1870 and 1906 .

As we have already seen, the introduction of the Poor Law Amendment Act in 1834 led to a sharp reduction in the number of able-bodied men in receipt of outdoor relief and a significant decline in the overall level of poor law expenditure in England and Wales, but the number of paupers began to rise once more during the 1860 s and this led to renewed calls for a return to the 'principles of 1834 ' and a further crackdown on relief payments (Harris 2004: 53-4). However, although the 
number of claimants fell by more than 300,000 (from 917,890 to 571,892 ) between 1871 and 1877 , the late-1860s and 1870 s also witnessed a number of other developments which may have been less eye-catching in themselves, but also betokened the emergence of a rather different attitude to the question of poor relief. Perhaps the most important of these was the gradual separation, in London at any rate, of the poor relief functions of the poor law from its medical functions, with the creation of the Metropolitan Asylums Board. This measure created a separate administrative authority for the organisation of hospital services, and marked the first stage in a process which gradually enabled an increasing number of people to receive medical assistance from the public authorities without suffering any loss of personal or civic status (Harris 2004: 97).

The second half of the nineteenth century also saw a degree of convergence between the Anglo-Welsh, Scottish and Irish Poor Laws. As we have already seen, when the Poor Law was introduced to Ireland in 1838, the Government had intended that relief would only be provided inside a workhouse but it was forced to abandon this restriction in 1847 and, by the start of the 1880 s, it has been estimated that almost forty per cent of Irish paupers were receiving relief in their own homes (Crossman 2014: 45). In Scotland, it had been expected that the introduction of the New Poor Law would enable parishes to generate more money to pay for poor relief by reinforcing their right to levy a local tax, or assessment. However, despite this, the Scottish poor law authorities continued to spend less money on poor relief, and to relieve a smaller proportion of their populations, than their Anglo-Welsh counterparts (Crowther 1990; Harris 2019).

In addition to the gradual extension of medical rights under the poor law (reinforced by the decision to admit non-paupers to infectious disease hospitals after 1871 and the promulgation of the Medical Relief (Disqualifications Removal) Act of 1885), the last three decades of the nineteenth century also witnessed a 
series of other developments which bore directly on the question of poverty itself. In 1870, when Parliament introduced the Forster Education Act, it gave school boards the power to remit fees for children whose parents were unable to afford the cost of sending them to board schools, and after 1891 the vast majority of children in England and Wales became exempt from the payment of elementary school fees altogether. The Education (Scotland) Act of 1872 also granted school boards the power to remit fees and elementary school fees were abolished for Scottish pupils in 1899 (Devine 2012: 397). New measures were also initiated to deal with the problems of unemployment and to investigate the incidence of poverty in old age. In 1886, Joseph Chamberlain issued the first of a series of Circulars authorising the establishment of public works schemes during periods of cyclical unemployment, and in 1894 the Royal Commission on the Aged Poor was charged with investigating the problem of poverty in old age. Once again, it would be easy to exaggerate the practical importance of these initiatives, particularly in the shortterm, but they were nevertheless indicative of a growing awareness of the limitations of existing approaches to social policy (Harris 2004: 55-8).

The 1870 s and 1880 s also witnessed a number of other significant developments in the area of health policy. As we have just seen, the provision of therapeutic services by public authorities continued to be closely linked to the poor law, but many local authorities began to build their own infectious disease hospitals (which came under municipal rather than poor law control), and it became much easier to receive medical assistance without suffering the stigma or disabilities associated with pauperism (Harris 2004: 97). However, the most radical changes occurred in relation to the preventive or environmental medical services. The Sanitary Act of 1866 extended some of the provisions of the 1848 Public Health Act to Ireland and expanded the legal definition of 'nuisances' prejudicial to health, but its main innovation was the decision to compel local authorities to inspect their 
districts and exercise their basic powers (Harris 2004: 111; Considine and Dukeley 2009: 88). The growing importance of public health was also underlined by the passage of the Public Health (Scotland) Act of 1867 and the Public Health Act of 1875 , and by the introduction of a series of Acts addressing such issues as the sale of food and drugs, the prevention of lead poisoning, and the purification of the water supply. The period also witnessed a substantial increase in the value of the loans contracted by local authorities for public works, including the construction of new sewers (Harris 2004: 111; Harris and Hinde 2019).

Although Szreter's (2002b: 4) suggestion that the period between 1870 and 1914 witnessed 'colossal and ever-increasing investments' in the improvement of local housing stock may be a little misleading, the period was nevertheless notable for a series of legislative innovations. In 1868 and 1875 Parliament introduced the first slum clearance acts, but these had only a limited impact because of the failure to build substantial numbers of new properties to replace those which had been demolished. However, the Housing of the Working Classes Act of 1890 gave local authorities the power to construct additional housing for more affluent workers in suburban areas in the hope that this would 'free up' housing at the bottom of the market for the more poorly-paid. In Ireland, a new body - the Congested Districts Board - was set up in 1891 to deal with problems of congestion and overcrowding in western districts. As in many other cases, the practical impact of much of this legislation was limited (only around five per cent of all the houses constructed between 1890 and 1914 were built by local authorities), but the legislation pointed the way for the much more significant expansion of local authority housing after 1919 (Considine and Dukelow 2009: 19; Harris 2004: 132-3).

Perhaps the most important policy innovation between 1870 and 1900 was the introduction of the Forster Education Act of 1870. This Act gave local ratepayers the power to establish school boards in areas where the existing level of elementary edition. 
education was deemed inadequate and allowed them to raise money for the support of these schools from local rates, and similar (though more extensive) changes were introduced to Scotland in 1872 (McDermid 2015: 190-4). Forster's Act did not make elementary education compulsory or free, but it paved the way for both, and by 1900 more than half of all the children between the ages of five and twelve who were attending publicly-supported schools in England and Wales were attending board schools, and many school boards were also providing voluntary classes for children above this age (Harris 2004: 144-7). In Scotland, education was made compulsory for children between the ages of five and thirteen but school attendance was only made compulsory in Ireland in 1892 , and even then compulsion was confined to children in urban areas (Akenson 1973: 13). Nevertheless, it is perhaps not surprising that observers such as A.V. Dicey (1962: liii) should have regarded the passage of Forster's Act as the true beginning of what subsequently came to be seen as late-Victorian and Edwardian collectivism.

Thought provoker: The Education Act of 1870 has often been regarded as one of the major landmarks in the history of state welfare intervention. It enabled School Boards to establish their own public elementary schools and gave them the power to make education compulsory for children between the ages of five and ten in their areas. However, many parents resented the introduction of compulsory education and this led to several prosecutions for non-attendance (see e.g. Hurt 1979: 188213; Humphries 1981: 62-9; Davin 1996: 98-102). Why might some parents have been reluctant to take advantage of the opportunities the Act provided? 


\section{Liberal welfare and the 'social service state'}

By the early-twentieth century, there was a growing recognition of the problem faced by the poor law, coupled with an increasing awareness of the extent of working-class poverty and its implications for the country's ability to maintain social stability and protect its economic and military interests. However, despite these pressures, the main changes in welfare provision were not implemented within the structure of the poor law itself but alongside it, and this had profound implications for its longer-term future.

It is customary for historians to begin their accounts of the 'Liberal welfare reforms' with the Education (Provision of Meals) Act of 1906 . This was a relatively brief measure (containing only three clauses) which was designed primarily to encourage greater cooperation between local authorities and voluntary agencies, and its main aim was not so much to provide free school meals, as to facilitate the provision of meals to paying children which could be provided at cost price. However, the third clause of the Act recognised that there was also a minority of children who were 'unable by reason of lack of food to profit from the education provided for them', and whose parents were unable to pay, and for this reason the Act also allowed the local education authority to raise a small amount of money (not more than the yield of a halfpenny rate) to feed these children without charge. Similar changes were introduced to Scotland (under the Education [Scotland] Act) in 1908 and to Ireland (under the Education [Provision of Meals] [Ireland] Act) in 1914. These Acts did not lead to any huge increase in the number of children who received free meals at school, but they did represent a marked break with poor law orthodoxy, since meals were being provided to the children without any penalty to the parents, and this undoubtedly enraged many conservative commentators (Harris 2004: 157-8). As Dicey observed in 1914: 
No-one can deny that a starving boy will hardly profit from the attempt to teach him the rules of arithmetic. But it does not necessarily follow that a local authority must therefore provide every hungry child at school with a meal ... [or] that a father who first lets his child starve, and then fails to pay the price legally due from him for a meal ... should, under the Act of 1906, retain the right of voting for a Member of Parliament. Why a man who first neglects his duty as a father and then defrauds the state should retain his full political rights is a question easier to ask than to answer (Dicey 1962: I).

Although the Liberals also introduced a number of other measures affecting children (including the establishment of a national system of school medical inspection, the introduction of free places in secondary schools and the Children Act of 1908), these measures were probably rather less important than the introduction of old age pensions in 1908. The new Act provided a non-contributory pension of five shillings a week to pensioners who were over the age of seventy and whose annual income was less than $£ 21$, with a sliding scale of payments for individuals whose annual income was between $£ 21$ and $£ 3110$ s. When the scheme was first introduced, it was limited to individuals who met a small number of 'character' tests and who had not recently been in receipt of poor relief, but these measures were rescinded over the next few years (Harris 2004: 158-60). Although the Act only provided a comparatively small pension to "the very poor, the very respectable and the very old' (Thane 1982: 83; 1996: 77), it was nevertheless a further breach in the wall of traditional poor law thinking and it prompted the Prime Minister, Herbert Asquith, to insist that it was not a final destination, but a 'new departure' on an 'unmeasured road of future social progress' (Parliamentary Debates 1908: cols. 828-9).

Following the passage of the Old Age Pensions Bill, the government was able to turn its attention to a range of issues connected with the labour market. In 1909, Parliament approved legislation covering the establishment of labour exchanges, a Development Fund for the promotion of public works programmes during periods of cyclical unemployment, and trade boards, with the power to set minimum wages in a range of 'sweated industries'. The government also introduced the Housing edition. 
and Town Planning Act. This Act reinforced many of the provisions introduced by earlier Acts, such as the Housing of the Working Classes Acts of 1890, 1900 and 1903, but it broke new ground by giving official encouragement to the principle of town planning, and also sought to strengthen the local administration of public health services by preventing newly-appointed Medical Officers of Health from engaging in private practice and granting them greater security of tenure (Harris 2004: 160-1).

Although each of these measures was undoubtedly important, none was more so than the Finance Bill which the Chancellor, David Lloyd George, presented to Parliament in the same year. During the nineteenth century, the government had derived the bulk of its revenue from indirect taxation, but the growth of new obligations forced politicians of all parties to consider new ways of generating the revenue on which public expenditure depended. In 1903, Joseph Chamberlain had persuaded the Conservative party to abandon its historic support for free trade in favour of tariff reform, but the Liberals believed that new revenue could best be raised by introducing a more graduated form of income tax and increasing death duties. The new proposals, which were finally approved in 1910 , led to a significant increase in the proportion of all revenue which was derived from income tax, and in the proportion of income tax revenue derived from higher earners (Harris 2004: 161-2).

The long-drawn out passage of what became known as the 'People's Budget' enabled the government to proceed with its plans for the creation of a new system of national insurance. During the nineteenth century, a growing proportion of working-class men (together with a much smaller number of working-class women) had sought to protect themselves against the financial hazards of sickness and old age (and, to a much lesser extent, unemployment) by taking out voluntary insurance through friendly societies or trade union benefit schemes and these 
schemes formed the basis - to some extent, at least - of the national scheme which the government introduced in 1911 (Harris 2004: 79-87). Part I of the National Insurance Act established a national health insurance scheme which was financed by contributions from workers, employers and the state, and which offered a range of health-related benefits, including free accommodation in a tuberculosis sanatorium, general practitioner treatment, a maternity allowance for insured women and the wives of insured men, and, most importantly, cash benefits of ten shillings a week for men and $7 \mathrm{~s} 6 \mathrm{~d}$ a week for women for the first twenty-six weeks of any incapacitating illness. Part II of the Act introduced a much more limited scheme, covering approximately 2.25 million workers, to deal with the problem of unemployment. This scheme was also financed by contributions from workers, employers and the state, and offered a flat-rate benefit of seven shillings a week for up to fifteen weeks in any 52-week period (Harris 2004: 162-3).

The Old Age Pensions and National Insurance Acts also represented a major step in the development of a 'UK-wide' welfare state. As we have already seen, the existing poor law was organised and funded through individual parishes and Poor Law Unions, with separate systems for England and Wales, Scotland and Ireland. However, the Old Age Pensions and National Insurance Acts were organised by central government and applied to the whole of the United Kingdom. The Old Age Pensions Act applied to any eligible person who 'for at least twenty years up to the receipt of any sum ... has been a British subject ... and residen[t] in the United Kingdom' (8 Edw. VII C. 40, section 2) and both the health insurance scheme and the unemployment insurance scheme also included contributors from across the UK (1 \& 2 Geo. V C. 55, schedule 1, part 1; and ibid., section 85).

Although national insurance has long been regarded as the flagship of the Liberal welfare reforms, it has not been without its critics. The flat-rate nature of the employees' contributions meant that the cost of insurance bore most heavily on 
those with the lowest incomes (Harris 1972: 380), and Paul Johnson (1996: 245-6) has complained that the introduction of national insurance substituted an 'individualistic' system of social protection for the more 'solidaristic' nature of the poor law. However, whilst neither of these criticisms should be treated lightly, it is also important to remember that the poor law was only able to preserve its 'solidaristic' features by imposing a highly-deterrent framework on the administration of poor relief and by stigmatising the recipients of poor relief. In view of this, it is perhaps less surprising that so many people should have been willing to accept the principle of national insurance as a welcome and worthwhile alternative to traditional poor law policies (Roberts 2000).

\section{CONTROVERSY AND DEBATE I. WORKING-CLASS ATTITUDES AND THE LIBERAL WELFARE REFORMS.}

In a famous article, Henry Pelling (1968: 1-2) once argued that 'the extension of the power of the state at the beginning of ... [the twentieth] century ... was by no means welcomed by members of the working class' and may even have been undertaken 'over the critical hostility of many of them, perhaps of most of them'. He claimed that this hostility was rooted in 'working class attitudes of suspicion or dislike towards existing institutions' - such as the Poor Law and the public vaccination service - 'which were the expression of national social policy'.

One of the major limitations of this debate is that it is often very difficult to find direct evidence of working-class views. Pelling's account was largely dependent on evidence obtained from official enquiries, such as the Royal Commission on the Poor Laws and the Interdepartmental Committee on Partial Exemption from School Attendance, observations by middle-class observers, such as the District Nurse, 
Margaret Loane, and from his analysis of the main topics discussed during General Elections between 1886 and 1914 . However other authors have been able to move beyond this, using evidence from oral historians, working-class autobiographies, and surveys carried out among the members of trade unions and friendly societies, and their investigations have yielded a rather more nuanced view. Pat Thane (1984: $879,882-92$ ) concluded that 'many poorer people ... were grateful for any amelioration of their hard lives', and that it was the leaders of trade unions who tended to be most sceptical of the motives of those advocating reform. However, even those who were hostile to state intervention were forced to recognise that some form of state welfare provision may be necessary to improve the conditions of the very poor, and during the 1890 s and 1900 s trade-unionists and friendlysociety members played an increasingly important role in campaigns for the introduction of such measures as school meals and school medical inspection, oldage pensions, the abolition of the Poor Law, the establishment of trade boards, and measures to reduce unemployment (Harris 2004: 154).

However, although it seems clear that working-class pressure was one of the reasons for the introduction of the Liberal welfare reforms, it was not the only one, and Thane (1984: 896) also pointed out that the reforms themselves 'were far from being complete victories for Labour; they were granted very much on Liberal terms'. It is also important to recognise the extent to which they were designed to fend off calls for more fundamental change, as Winston Churchill explained in relation to the introduction of unemployment insurance in 1909:

The idea is to increase the stability of our institutions by giving the mass of industrial workers a direct interest in maintaining them.... This scheme ... will help to remove the dangerous element of uncertainty from the existence of the industrial worker. It will give him an assurance that his home, got together through long years and with affectionate sacrifice, will not be broken up, sent bit by bit to the pawnshop, just because ... he falls out of work. It will make him a better citizen, a more efficient worker, [and] a happier man (quoted in Harris 1972: 365-6). 


\section{Questions}

- How did working-class people view the prospect of increased state intervention in welfare provision?

- What role did working-class pressure play in the introduction of the Liberal welfare reforms?

- What other factors also contributed to the introduction of these measures?

\section{Welfare between the wars}

Although the Liberal welfare reforms represented a major shift in the history of British social policy, their impact was almost immediately overshadowed by the outbreak of the First World War. The war severely disrupted many welfare services and forced the government to take a number of emergency measures, but it also generated a new sense of entitlement on the part of many working-class people and fuelled a wide-ranging debate on the future of welfare provision.

One of the most important changes (if not the most important change) in the infrastructure of welfare provision after 1918 was the expansion of the unemployment insurance scheme. As we have already seen, the original unemployment insurance scheme was set up under Part II of the National Insurance Act of 1911, and was designed to provide a short-term flat-rate benefit for a limited number of workers employed in a selected range of industries, but during the course of 1920 and 1921 this scheme was transformed by a series of changes which meant that by the end of 1921 it covered approximately 75 per cent of the employed workforce, and provided benefits which were intended not only to cover both short- and long-term periods of unemployment, but also to cater for the 
needs of both unemployed workers and their dependants. During the remainder of the 1920s and 1930s, the government introduced a number of other changes, many of which were designed to restrict access to the unemployment insurance fund and reduce overall levels of expenditure, but in spite of this the basic principle which had been established by the reforms of 1920 and 1921 remained intact, and by the end of the interwar period the overwhelming majority of unemployed workers were receiving benefits under the statutory unemployment insurance scheme (Harris 2004: 204-7).

Although the expansion of unemployment insurance represented the most dramatic change in the state's response to the problem of poverty, the period also witnessed important developments in other areas of anti-poverty policy. The number of workers covered by national health insurance increased from 15.9 million in 1918 to 21.6 million in 1938 , and there were also some significant (though by no means universal) improvements in the provision of municipal welfare benefits, such as school meals and the distribution of nutritional supplements at maternity and child welfare centres. One of the most important innovations was the development of a contributory pension scheme for those between the age of sixtyfive and seventy. This scheme was grafted on to the existing health insurance scheme and provided a basic pension of ten shillings a week for insured workers, the wives of insured men (where the man was over the age of sixty-five and his wife was aged between sixty-five and seventy), and the widows of insured men, with additional allowances for widows' children and orphans (Harris 2004: 211-6).

These changes in the overall framework of welfare support had profound implications for the oldest form of statutory welfare provision, the poor law. As we have already seen, the main aim of the New Poor Law after 1834 had been one of deterrence, but this attitude came under growing attack during the 1890s and early-1900s, and became increasingly difficult to sustain in many parts of the 
country after the end of the First World War. The role of the poor law (or public assistance, as it became known in England and Wales after 1930) was also affected by the development of alternative welfare systems. During the nineteenth century, the poor law had formed the bedrock of statutory welfare support, but during the interwar period it acted more as a back-up, providing supplementary benefits to individuals who received the majority of their support from one of the contributory schemes, but still required additional support to 'make ends meet'. In this respect, then, it is at least arguable that there was rather more continuity between the public assistance scheme of the late-1930s and the national assistance scheme of the 1940s and 1950s than postwar welfare rhetoric might suggest (Harris 2004: 2024).

The interwar years also witnessed important developments in the provision of hospital services. Although the number of publicly-controlled hospital beds remained largely unchanged, an increasing proportion of these hospitals began to develop acute medical services, with the result that the number of patients treated in public hospitals increased substantially. There were also important changes in the administrative structure of public hospital provision. During the nineteenth and early-twentieth centuries, the majority of public-sector hospitals had been under the control of poor law authorities, but in 1929 these were transferred to the local county, county borough or burgh councils, and these authorities were also given the power to transfer responsibility for hospital administration from their public assistance committees to their public health committees. There has been some debate over the extent and pace of the process of transfer, or 'appropriation', but by the end of the 1930s more than half the public-sector hospital beds in England and Wales were under public health control (Levitt 1988: 135, 160-2; Harris 2004: 231-3). 
These changes in the development and administration of the public-sector hospital service were matched by equally significant changes in the voluntary hospital sector. The voluntary hospitals originated during the eighteenth and nineteenth centuries as privately-controlled institutions supported by voluntary contributions, but during the interwar years they began to see themselves not so much as charitable institutions for the deserving poor, but rather as general medical institutions for the population at large. This change in the character of the voluntary hospitals encouraged new demands for better coordination between the public and voluntary hospital sectors and also for the management of voluntary hospitals to become more accountable to the populations they served, and these twin demands for coordination and accountability both played an important part in the debates over the plans for a national health service during the Second World War (Harris 2004: 227-31).

In legislative terms, some of the most dramatic changes in welfare policy affected the area of housing. Although local authorities had enjoyed at least the theoretical power to construct their own houses since the mid-nineteenth century, only around one-quarter of one per cent of all householders lived in municipallyowned accommodation on the eve of the First World War. However, in 1919 Parliament passed two Acts, the Housing and Town Planning, etc. Act and the Housing (Additional Powers) Act, which provided central government subsidies to local authorities and private builders to enable them to build new homes for working-class use, and in 1930 the second Labour government introduced the Greenwood Housing Act, which earmarked separate subsidies for the construction of replacement housing for individuals who were to be evicted from their existing properties under slum clearance schemes. During the period as a whole, more than 1.1 million homes were built by local authorities between 1 January 1919 and 31 March 1939, and more than 2.8 million homes were built by private builders, of 
which approximately 430,000 were constructed with the aid of government subsidies (Harris 2004: 245-54, 261).

Historians of social policy have often seen the interwar period as a wasted period in terms of educational development, and this has led some commentators to conclude that it is not worthy of consideration at all (see Gilbert 1970: viii). The reduction in the birth rate should have enabled interwar governments to achieve significant improvements in educational provision, but there was only a small increase in the number of pupils attending selective secondary schools, and the school-leaving age remained fixed at fourteen despite a series of attempts to raise it. However, the period did see some important changes in the organisation of the elementary school system. During the first half of the 1920s, the majority of children remained in the same 'all-age' schools throughout their educational careers, but in January 1925 the Board of Education argued that all children should pass from 'junior' to 'senior' education at the age of eleven, and the Board's Consultative Committee (the Hadow Committee) called for a similar break to be made between 'primary' and 'secondary' education when it published its report on The education of the adolescent in the following year. This report contributed to the process which became known as 'Hadow reorganisation' and, by the end of the 1930s, more than sixty per cent of the pupils attending elementary schools in England and Wales were being educated in schools which had undergone some form of reorganisation along these lines (Harris 2004: 270-3).

Although there were many similarities between the Anglo-Welsh and Scottish education systems, there were also differences. As we have already seen, the Education (Scotland) Act of 1872 was a rather more expansive measure than William Forster's Elementary Education Act of 1870, and this enabled Scottish School Boards to make rather more extensive provision for the development of more advanced forms of education for older pupils. However, in 1923 the Scotch Education 
Department introduced a new set of regulations which were quite similar to the regulations which the Board of Education introduced in England and Wales in 1925. Within England and Wales, the introduction of these changes and the subsequent process of 'Hadow reorganisation' have often been regarded as precursors to the development of a reformed system of primary and secondary schools after 1945, but the Circular which the Scotch Education Department introduced in 1923 has attracted much more criticism. Thomas Devine (2012: 406) argued that the new policies "branded the majority of pupils as "failures", intensified social divisions and produced a secondary education system of glaring inequality', although Lindsay Paterson (2015: 34) has suggested that they also increased access to secondary education for pupils from lower-middle-class and skilled-working-class backgrounds.

In 1921, Ireland was partitioned. The six northern counties became part of Northern Ireland, and the remaining 26 counties separated from the United Kingdom to form the Irish Free State. During the nineteenth and early-twentieth centuries, the Irish education system had been dominated by the Catholic and Protestant churches and there had been little attempt to develop a more secular system along the lines of either the Elementary Education Act of 1870 or the Education (Scotland) Act of 1872. In 1922, the Government appointed a Committee of Enquiry - the Lynn Committee - to investigate the future development of public education in Northern Ireland, and its recommendations formed the basis of Lord Londonderry's Education Act ( $13 \& 14$ Geo. V. C. 21$)$ in the following year. The new Act made education compulsory for children in Northern Ireland between the ages of six and fourteen (with the proviso that children could be employed on a parttime basis in certain occupations from the age of twelve) but failed to challenge the existing system of denominational education. The result was that Northern Irish 
education continued to be segregated on religious lines throughout the interwar period (and beyond) (Akenson 1973: 39-72).

\section{The Second World War and after}

By 1939 it was clear that the structure of the British welfare services had expanded considerably, but there were still large numbers of people who lived in squalid and overcrowded accommodation, who were unable to obtain adequate medical care, or who continued to depend on means-tested public assistance benefits. The outbreak of war heightened public awareness of the implications of many of these issues and led to the publication of a series of reports with proposals for change.

Of all the reports issued during the war, none is more famous that the Beveridge Report of 1942 (Parliamentary Papers 1942). William Beveridge was one of the architects of the Labour Exchanges Act of 1909, and had been summoned out of retirement to advise the wartime Minister of Labour, Ernest Bevin, in 1940. However, in June 1941 he was invited by Arthur Greenwood, the Minister-withoutPortfolio, to chair an enquiry into the development of a consolidated scheme of social insurance. According to his biographer, José Harris (1977: 362-77), Beveridge was initially quite reluctant to take on this role, but he soon realised that it offered him a unique opportunity to develop proposals for a much more fundamental reform of welfare provision.

The primary aim of the Beveridge Committee was to frame proposals for the development of a more consolidated scheme of social insurance. Beveridge advocated a single scheme providing insurance against sickness, unemployment and old age, and said that it should provide benefits to the entire population, and not just manual workers. He also argued that these benefits should be sufficient to 
meet the recipients' subsistence needs, and this became the focus of particular controversy during the remainder of the war years (Harris 2004: 290).

Beveridge also included two other sets of recommendations - one implicit and one explicit - which had major implications for the government's welfare role. He argued that the new scheme of social insurance would only work if it was supported by action in three other sets of areas: the provision of family allowances for all families with children, whether they were in work or not; the development of a comprehensive health and rehabilitation service to enable every individual to maintain themselves in good health and obtain adequate medical care when they needed it; and the prevention of mass unemployment. He also said that 'Want' was only one of the 'five giants' on the road to social reconstruction, and that the government's attack on Want had to be accompanied by a parallel assault on the giants of Ignorance, Disease, Idleness and Squalor (Harris 2004: 290-1).

The attack on Idleness was one of the most important 'Assumptions' on which the Beveridge Report was based. During the 1920 s and 1930 s, unemployment had been a major cause of hardship and the cost of supporting unemployed people and their families had been a significant drain on the government's finances, but the Treasury argued that there was very little which governments could do to reduce unemployment, other than by seeking to restore normal trading conditions. However, in June 1944 the Government published a White Paper on Employment Policy (Parliamentary Papers 1944a) which represented a major departure from the 'Treasury view'. It marked the first official acceptance of the idea that governments had a legitimate role to play in maintaining a high and stable level of employment under normal peacetime conditions.

After Idleness and Want came Ignorance. As we have already seen, the interwar period witnessed a number of important change in the organisation of public education but the process of 'Hadow reorganisation' remained incomplete and the 
school leaving age had still not been raised since 1918. However, in 1943 the Government published a White Paper on Educational Reconstruction (Parliamentary Papers 1943), and this formed the basis of the Education Act which the President of the Board of Education, 'Rab' Butler, introduced in the following year. Although the new Act ignored the position of the country's private fee-paying schools and sidestepped the controversial question of the structure of secondary education beyond the age of eleven, it also introduced a number of important changes. It removed one of the major barriers to the coordination of primary and secondary education by placing responsibility for both forms of education in the hands of a single education authority in each area; it insisted that all children should move from primary schools to some form of secondary school at the age of eleven; and it raised the status of education at the level of central government by converting the Board of Education into a fully-fledged Ministry. It also abolished the payment of fees in all state secondary schools and raised the school leaving age from fourteen to fifteen, and gave the Minister of Education the power to raise the school leaving age to sixteen as soon as circumstances permitted (Harris 2004: 292-3). Similar changes were introduced under the Education (Scotland) Act of 1945 and the Education Act (Northern Ireland) of 1947 (Akenson 1973: 180-4). However, although the first of these Acts also drew a clear distinction between primary and secondary education, it did not stipulate the age at which children should move from one to the other ( $8 \& 9 \mathrm{Geo}$. VI, C. 37 , section 1$)$.

Although some historians have suggested that the politics of educational reform were comparatively straightforward, the reform of health service provision was much less so. This was partly the result of the attitude of the medical profession itself. During the 1930s, there was a growing consensus that the existing system of national health insurance needed to be extended to provide better access to medical care for those sections of the population - principally women and children - 
who were not already covered by it, but it was also assumed that there would continue to be significant scope for the continuation of private medical practice. However, when Beveridge published his report in 1942, he argued that the new social insurance scheme should cover the entire population, in which case the whole population would become entitled to free medical care. This proposal attracted fierce opposition within the medical profession, because they believed that it would lead to the erosion of private practice and pose a significant threat to medical independence.

This was not the only way in which the Beveridge Report affected the debate over health care. During the interwar period, the voluntary hospitals had begun to derive an increasing proportion of their income from patients' payments and contributory insurance schemes, but Beveridge's proposals threatened to undermine these sources of income by suggesting that everyone would be covered by the Government's social insurance scheme. The British Medical Association also believed that people would be much less inclined to support the voluntary hospitals as charitable institutions in the atmosphere created by what it called 'the government's “free-for-all” propaganda' (Harris 2004: 294-6).

In view of these difficulties, it is perhaps not surprising that the development of concrete plans for the reform of the country's health services should have proceeded more slowly than the development of plans for educational reform, but it is still important to recognise the importance of the changes which did occur. In February 1944 the Ministry of Health and the Department of Health for Scotland published a joint White Paper in which they set out their initial proposals for the development of a comprehensive system of health care. Although many of the details of these proposals were subsequently changed, the White Paper nevertheless established the basic principles on which the National Health Service would develop after 1948. Its opening paragraph read as follows: 
The Government have announced that they intend to establish a comprehensive health service for everybody in this country. They want to ensure that in future every man and woman and child can rely on getting all the advice and treatment and care which they may need in matters of personal health; that what they get shall be the best medical and other facilities available; that their getting these shall not depend on whether they can pay for them, or on any other factor irrelevant to the real need - the real need being to bring the country's full resources to bear upon reducing ill-health and promoting good health in all its citizens (Parliamentary Papers 1944b: 1).

The last of Beveridge's five giants was Squalor. Although significant progress had been made before 1939 , many people continued to live in insanitary and overcrowded conditions on the eve of the Second World War, and these problems were exacerbated by the outbreak of hostilities. The war diverted resources from the construction of new housing and it has been estimated that approximately 475,000 homes (out of a total of approximately 11.5 million) were either destroyed or rendered uninhabitable by enemy action. In 1944, the Prime Minister, Winston Churchill, announced plans for the immediate construction of 500,000 prefabricated houses and promised to build 2-300,000 permanent homes during the first two years of peace, but the Labour party promised to build between four and five million new homes, the majority of which would be supplied by local authorities. This marked a reversion to an earlier view of the role of council houses, in which local authorities would build homes for general needs, and not just for the poorest sections of the population (Harris 2004: 299-300).

\section{CONTROVERSY AND DEBATE II. CONSENSUS AND SOCIAL POLICY DURING THE} SECOND WORLD WAR.

In 1950, one of the pioneering figures of academic social policy in Britain, Richard Titmuss published a magisterial survey of the history of social policy during the Second World War. In it, he not only provided a vivid account of the social challenges posed by the war, but also attempted to draw a connection between the Forthcoming in H. Bochel and G. Daly, eds., Social policy, London: Routledge, $4^{\text {th }}$ edition. 
events of war and the development of the postwar welfare state. He was particularly impressed by the importance of three critical events in the first year of war: the evacuation of mothers and children in September 1939; the evacuation of British soldiers from Dunkirk; and the Blitz. He claimed that the popular reaction to these three events generated what he called 'the war-warmed impulse of people for a more generous society' (1950: 507-8).

In addition to exploring the specific effect of the Second World War on the development of social policy, Titmuss also attempted to develop a more general theory, based on the ideas of the sociologist, Stanislaw Andrzejewski (1954), about the relationship between war and social policy more generally. In a lecture originally delivered in 1955 , he wrote that

The aims and content of social policy, both in peace and in war, are thus determined - at least to a substantial extent - by how far the cooperation of the masses is essential to the successful prosecution of war. If this cooperation is thought to be essential, then inequalities must be reduced, and the pyramid of social stratification must be flattened (1987: 111).

Whilst few historians would deny that the war saw some changes in social policy, many have questioned the extent to which all classes and all sections of the population shared Titmuss's concept of a 'war-warmed impulse to a more generous society' (see e.g. Harris 1981; Macnicol 1986; Jefferys 1987), and others have queried the extent to which either the First or the Second World Wars introduced any major discontinuities (Edgerton 2018). At the same time, it is also clear that the war did have some effect in helping to alert official minds to the extent of existing social problems. As authors of a London County Council survey explained in 1943:

The experience of evacuation has - in advance of the Beveridge Report - brought home to social workers, and indeed to the nation at large, how real and formidable are the giants of Want, Ignorance and Squalor, and how sadly they are hindering, in town and country alike, the wellbeing of the rising generation (quoted in Welshman 1997: 53; see also Harris 2004: 286). 
In 1990, Rodney Lowe attempted to reconcile these conflicting accounts by examining the extent of consensus at three different levels: among politicians, within the civil service, and among the public at large. He concluded that 'at all levels of society and in each area of welfare policy, consensus - defined as an historically-unusual degree of agreement - was not a mirage in the 1940s' (1990: 180). However, he also argued that this was an increasingly passive consensus, and that the failure to develop a more active consensus after 1945 lay at the heart of Britain's problems in the postwar era (1990: 181-2).

\section{Questions}

- How did the outbreak of war affect the debate over social policy?

- Did it promote the existence of a wartime 'consensus'?

- How radical were the policies which were promoted during the war?

- What impact did these policies have on the development of social policy after $1945 ?$

- What were the limitations of the 'wartime consensus' and how were these reflected in the development of peacetime policies?

\section{Conclusion}

At the end of the Second World War, Britain emerged victorious but shattered from six years of hostilities. However, despite these difficulties it also possessed a series of plans for the reform of social policy and the development of what came to be known as the 'welfare state' (Lowe 2005: 13). These plans provided the initial starting point for many of the policies which will discussed in the following chapters of this book. 


\section{Summary}

This chapter has examined the history of social welfare provision in Britain from the beginning of the nineteenth century to the end of the Second World War. Although the chapter has recognised the importance of the 'mixed economy of welfare' and the contributions made by the different elements within this mixed economy, including the informal and voluntary sectors, the family and the market, the main focus has been on the role of the state. This has been reflected in a number of ways, including the following:

- The acknowledgement of a basic level of responsibility for welfare provision in England and Wales under the Poor Laws of 1597 and 1601.

- The regulation of living and working conditions through such measures as the Factory Acts of 1819, 1825 and 1833, and the introduction of building bye-laws under successive Public Health Acts.

- The provision of public services, such as the development of public education and the expansion of public health service provision.

- The introduction of new forms of income support and other changes in welfare policy as part of the Liberal welfare reforms of 1906-14.

- The introduction of publicly-subsidised local-authority housing and the gradual expansion of other forms of public welfare provision between 1914 and 1939.

- The emergence of plans for the establishment of a more comprehensive 'welfare state' between 1939 and 1945 . 
DISCUSSION AND REVIEW TOPICS

1. In what sense, if any, is it appropriate to talk about the 'Victorian origins of the welfare state' in Britain between circa 1800 and 1870?

2. How important were the territorial differences between the different poor laws which operated in England and Wales, Scotland and Ireland during the nineteenth and early-twentieth centuries, and what impact might these have had on the long-term development of UK-wide social policies?

3. Did the period between 1870 and 1906 witness any important changes in attitudes to the relief of poverty or other aspects of social policy?

4. In what ways did the introduction of the Liberal welfare reforms of 1906-14 represent a significant change in the relationship between the state and the individual?

5. Why did public expenditure on the social services increase in Britain between 1914 and $1939 ?$

6. To what extent did the Beveridge Report and the 'White Paper chase' of 1943-4 lay the foundations of Britain's postwar welfare state?

\section{Further reading}

Boyer, G. (2019), The winding road to the welfare state: economic insecurity and social welfare policy in Britain, Princeton: Princeton University Press. The first half of this book contains a set of essays on the history of the poor law in England and Wales. The second part integrates this account with a broader account of welfare policies between 1906 and 1945 .

Finlayson, G. (1994), Citizen, state and social welfare in Britain 1830-1990, Oxford: Oxford University Press. The current chapter has focused on the growth of state welfare provision between 1800 and 1945; this book explores the same issues from the point of view of changes in the voluntary sector.

Fraser, D. (2017), The evolution of the British welfare state: a history of social policy since the Industrial Revolution Basingstoke: Palgrave ( $5^{\text {th }}$ edition). This is the fifth 
edition of a text which was first published in 1973, and it continues to provide a highly accessible and readable introduction to the history of British social policy.

Harris, B. (2004), The origins of the British welfare state: social welfare in England and Wales, 1800-1945, Basingstoke: Palgrave. This book is designed to provide a comprehensive account of the development of all aspects of British welfare policy. It includes much of the detailed evidence which forms the basis of this chapter.

Lowe, R. (2005), The welfare state in Britain since 1945, Basingstoke: Macmillan (3 edition). This book has become the standard academic work on the history of the welfare state in Britain after 1945.

Renwick, C. (2017), Bread for all: the origins of the welfare state, London: Allen Lane. This book aims to provide a popular account of the history of social policy 'from the Poor Law to Beveridge'. It pays particular attention to the personalities of some of the key figures who helped to shape welfare policy.

Thane, P. (1996), Foundations of the welfare state, London: Longman ( $2^{\text {nd }}$ edition). The first edition of this book was published in 1982 . The second edition was thoroughly revised, with the introduction of new material on the relationship between women and welfare and the contribution of the voluntary sector. A distinguishing feature of both editions was the inclusion of international comparisons.

\section{Some useful websites}

http://www.workhouses.org.uk/ - For much of the nineteenth and early-twentieth centuries, the workhouse was one of the central institutions of British social policy. This website provides a fascinating guide to its buildings, inmates, staff and administrators, even its poets.

http://medphoto.wellcome.ac.uk/ - This website provides access to a range of historical photographs illustrating aspects of nineteenth and early-twentieth century hospitals.

http://www.nationalarchives.gov.uk/ - This is the website of the UK's National Archives. The Archives include administrative records covering all aspects of welfare history. An increasing number of records are now being made available online.

http://www.nationalarchives.gov.uk/ - History and Policy was founded by a group of historians in 2002 with the explicit aim of using history to address current issues in public policy. This website provides access to a wide range of papers, covering all aspects of welfare policy.

https://login.westlaw.co.uk/ - This website provides access to many of the major pieces of legislation passed in the UK since the start of the thirteenth century. Many more recent Acts can also be accessed via www.legislation.gov.uk. 


\section{Appendix 1. Prime Ministers and political complexion of governments}

1783 William Pitt the Younger (Tory)

1801 Henry Addington (Tory)

1804 William Pitt the Younger (Tory)

1806 Lord Grenville (Whig)

1807 Duke of Portland (Tory)

1809 Spencer Percival (Tory)

1812 Lord Liverpool (Tory)

1820 Accession of King George IV

1827 George Canning (Tory)

1827 Viscount Goderich (Tory)

1828 Duke of Wellington (Tory)

1830 Accession of King William IV

1830 Earl Grey (Whig)

1834 Viscount Melbourne (Whig)

1834 Sir Robert Peel (Tory)

1835 Viscount Melbourne (Whig)

1837 Accession of Queen Victoria

1841 Sir Robert Peel (Tory)

1846 Earl Russell (Liberal)

1852 Earl of Derby (Tory)

1852 Earl of Aberdeen (Tory)

1855 Viscount Palmerston (Liberal)

1858 Earl of Derby (Conservative)

1859 Viscount Palmerston (Liberal)

1865 Earl Russell (Liberal)

1866 Earl of Derby (Conservative)

1868 Benjamin Disraeli (Conservative)

1868 William Ewart Gladstone (Liberal)

1874 Benjamin Disraeli (Conservative)

1880 William Ewart Gladstone (Liberal)

1885 Marquess of Salisbury (Conservative)

1886 William Ewart Gladstone (Liberal)

1886 Marquess of Salisbury (Conservative)

1892 William Ewart Gladstone (Liberal)

1894 Earl of Rosebery (Liberal)

1895 Marquess of Salisbury (Conservative)

1901 Accession of King Edward VII

1902 Arthur James Balfour (Conservative)

1905 Henry Campbell Bannerman (Liberal)

1908 Herbert Henry Asquith (Liberal)

1910 Accession of King George V

1916 David Lloyd George (Coalition)

1922 Andrew Bonar Law (Conservative)

1923 Stanley Baldwin (Conservative)

1924 James Ramsay MacDonald (Labour)

1924 Stanley Baldwin (Conservative)

1929 James Ramsay MacDonald (Labour)

1931 James Ramsay MacDonald (National Government)

1935 Stanley Baldwin (National Government)

1936 Accession and abdication of King Edward VIII; accession of King George VI

1937 Arthur Neville Chmaberlain (National Government)

Forthcoming in H. Bochel and G. Daly, eds., Social policy, London: Routledge, $4^{\text {th }}$ edition. 
1940 Winston Leonard Spencer Churchill (Coalition)

1945 Clement Richard Attlee (Labour)

\section{Appendix 2. Significant events in politics and social policy}

\begin{tabular}{|c|c|}
\hline \multicolumn{2}{|r|}{ 1793-1815: French Revolutionary Wars } \\
\hline 1798 & First edition of Thomas Malthus, An essay on the principle of population \\
\hline 1799 & Introduction of income tax by William Pitt the Younger \\
\hline \multicolumn{2}{|r|}{ 1800: Act of Union between Great Britain and Ireland } \\
\hline 1802 & Temporary suspension of income tax; Health and Morals of Apprentices Act \\
\hline 1816 & Withdrawal of income tax \\
\hline 1819 & Factory Act \\
\hline 1825 & Factory Act \\
\hline 1831 & Establishment of the Board of Commissioners for National Education in Ireland \\
\hline 1832 & Parliamentary Reform Act \\
\hline 1832 & Appointment of Royal Commission on the Poor Laws \\
\hline 1833 & Factory Act; Education Grant \\
\hline 1834 & Poor Law Amendment Act; formation of Poor Law Commission \\
\hline 1838 & Poor Relief (Ireland) Act \\
\hline 1839 & Creation of the Privy Council Committee on Education \\
\hline 1842 & Reintroduction of income tax \\
\hline 1845 & Poor Law (Scotland) Act \\
\hline \multicolumn{2}{|r|}{ 1845-7: Irish Potato Famine } \\
\hline 1847 & Formation of the Poor Law Board \\
\hline 1847 & Irish Poor Relief Extension Act \\
\hline 1848 & Public Health Act \\
\hline \multicolumn{2}{|r|}{ 1853-4: Crimean War } \\
\hline 1866 & Sanitary Act \\
\hline 1867 & Parliamentary Reform Act \\
\hline 1867 & Public Health (Scotland) Act \\
\hline 1867 & Creation of the Metropolitan Asylums Board \\
\hline 1868 & Artisans' and Labourers' Dwellings Act (Torrens Act) \\
\hline 1870 & Elementary Education Act (Forster's Act); creation of School Boards \\
\hline 1871 & $\begin{array}{l}\text { Creation of Local Government Board; publication of LGB Circular 20, launching the } \\
\text { 'Crusade against Outdoor Relief }\end{array}$ \\
\hline 1872 & Education (Scotland) Act \\
\hline 1872 & $\begin{array}{l}\text { Public Health Act, compelling all County Boroughs to appoint Medical Officers of } \\
\text { Health }\end{array}$ \\
\hline 1875 & Public Health Act; Artisans' and Labourers' Dwellings Improvement Act (Cross Act) \\
\hline 1880 & $\begin{array}{l}\text { Elementary Education Act (Mundella's Act), making education compulsory } \\
\text { throughout England and Wales }\end{array}$ \\
\hline 1884 & Parliamentary Reform Act \\
\hline 1885 & Parliamentary Reform Act \\
\hline 1885 & Medical Relief (Disqualifications Removal) Act \\
\hline 1886 & Chamberlain Circular, authorising the use of public works to relieve unemployment \\
\hline 1890 & Housing of the Working Classes Act \\
\hline 1891 & Abolition of fees in public elementary schools in England and Wales \\
\hline 1894 & $\begin{array}{l}\text { Local Government Act (enabled women and non-property-owners to stand for } \\
\text { election to Boards of Poor Law Guardians and extended voting rights to all county- } \\
\text { council and parliamentary electors) }\end{array}$ \\
\hline 1894 & Appointment of the Royal Commission on the Aged Poor \\
\hline 1899 & Abolition of fees in public elementary schools in Scotland \\
\hline
\end{tabular}

Forthcoming in H. Bochel and G. Daly, eds., Social policy, London: Routledge, $4^{\text {th }}$ edition. 
1906 Education (Provision of Meals) Act

1907 Education (Administrative Provisions) Act, authorising the creation of a school medical service

1908 Children Act; Old Age Pensions Act

1908 Education (Scotland) Act (empowering school boards in Scotland to make arrangements for the medical inspection and feeding of schoolchildren)

1909 Housing and Town Planning Act; Development and Road Improvement Fund Act; Labour Exchanges Act; Trade Boards Act; introduction of 'People's Budget'

1911 National Insurance Act

1914 Education (Provision of Meals) (Ireland) Act

1914-18: First World War

1915 Introduction of rent controls (Increase of Rent and Mortgage Interest (War Restrictions) Act)

1918 Representation of the People Act (enabled women over the age of thirty to vote in Parliamentary elections)

1918 Maternity and Child Welfare Act

1919 Creation of Ministry of Health; introduction of subsidised housing through the Housing and Town Planning, etc. Act and the Housing (Additional Powers) Act

1920 Unemployment Insurance Act (extension of original scheme to the majority of manual workers and non-manual workers earning less than $£ 250$ per year)

1921 Unemployment Insurance Act (introduction of 'uncovenanted' benefit for workers who had exhausted their right to unemployment benefit under the original scheme); Unemployed Workers' Dependants (Temporary Provisions) Act (introduction of allowances for the dependants of unemployed workers) 1922: Creation of the Irish Free State

1923 Education Act (Northern Ireland)

1923 Chamberlain Housing Act

1924 Wheatley Housing Act

1925 Widows', Orphans' and Old Age Contributory Pensions Act

1926 Publication of the Hadow Report on The education of the adolescent

1928 Representation of the People Act (extended voting rights to all women over the age of 21, thereby giving women the same entitlement to vote as men)

1929 Widows', Orphans' and Old Age Contributory Pensions Act; Local Government Act (abolishing Boards of Guardians and transferring their powers to local county or county borough councils)

1929 Local Government Acts passed in England and Wales and in Scotland, transferring poor law responsibilities to local councils

1930 Greenwood Housing Act

1931 Introduction of transitional payments scheme for workers who had been unemployed for more than six months

1932 Town and Country Planning Act

1933 Abolition of Wheatley Act housing subsidies

1934 Creation of Unemployment Assistance Board

1942 Report on Social Insurance and Allied Services (the Beveridge Report)

1943 White Paper on Educational Reconstruction

1944 Education Act (the Butler Act); White Papers on A National Health Service; Employment Policy; and The control of land use

1945 Education (Scotland) Act

1945 Family Allowances Act

1945 Disabled Persons (Employment) Act (Northern Ireland)

1946 National Insurance Act; National Insurance (Industrial Injuries) Act; National Insurance Act (Northern Ireland); National Insurance (Industrial Injuries) Act (Northern Ireland)

1946 National Health Service Act

1947 Town and Country Planning Act

1947 National Health Service (Scotland) Act

Forthcoming in H. Bochel and G. Daly, eds., Social policy, London: Routledge, $4^{\text {th }}$ edition. 
1947 Education Act (Northern Ireland)

1948 National Assistance Act; National Assistance Act (Northern Ireland)

1948 Health Services Act (Northern Ireland)

\section{References}

Akenson, D.H. (1973), Education and enmity: the control of schooling in Northern Ireland, 1920-50, Newton Abbott: David \& Charles.

Andrzejewski, S. (1954), Military organisation and society, London: Routledge and Kegan Paul.

Brewer, J. (1989), The sinews of power: war, money and the English state, 16881783, London: Unwin Hyman.

Considine, M. and Dukelow, F. (2009), Irish social policy: a critical introduction, Dublin: Gill and Macmillan.

Crossman, V. (2014), Poverty and the poor law in Ireland, 1850-1914, Liverpool: Liverpool University Press.

Crowther, M.A. (1990), 'Poverty, health and welfare', in W.H. Fraser and R.J. Morris, eds., People and society in Scotland. Vol. II: 1830-1914, Edinburgh: John Donald, 265-89.

Davin, A. (1996), Growing up poor: home, school and street in London 1870-1914, London: Rivers Oram Press.

Devine, T. (2012), The Scottish nation: a modern history, Harmondsworth: Penguin.

Dicey, A.V. (1962), Lectures on the relation between law and public opinion in England during the nineteenth century, London: Macmillan (first edition, 1905; second edition first published in 1914).

Edgerton, D. (2018), 'War and the development of the British welfare state', in $\mathrm{H}$. Obinger, K. Petersen and P. Starke, eds., Warfare and welfare: military conflict and welfare state development in western countries, Oxfrod: Oxford University Press, 200-29.

Edsall, N.C. (1971), The anti-poor law movement, 1834-44, Manchester: Manchester University Press.

Flinn, M.W. (1965), 'Introduction', in M.W. Flinn, ed., Report on the sanitary condition of the labouring population of Great Britain, by Edwin Chadwick, Edinburgh: Edinburgh University Press, 1-73.

Fogel, R.W. (1994), 'Economic growth, population theory, and physiology: the bearing of long-term processes on the making of economic policy', American Economic Review, 84, 369-95.

Gilbert, B. (1970), British social policy 1914-39, London: Batsford.

Harling, P. (1992), 'The power of persuasion: central authority, local bureaucracy and the New Poor Law', English Historical Review, 107, 30-53.

Harris, B. (2004), The origins of the British welfare state: social welfare in England and Wales, 1800-1945, Basingstoke: Palgrave Macmillan. 
Harris, B. (2014), 'Health and welfare', in R. Floud, J. Humphries and P. Johnson, eds., The Cambridge economic history of modern Britain. Vol. II: 1870 to the present, Cambridge: Cambridge University Press, 122-50.

Harris, B. (2019), 'Parsimony and pauperism: poor relief in England, Scotland and Wales in the nineteenth and early-twentieth centuries', Journal of Scottish Historical Studies, 39 (1), 40-74.

Harris, B. and Bridgen, P. (2007), 'Introduction: the "mixed economy of welfare" and the historiography of welfare provision', in B. Harris and P. Bridgen, eds., Charity and mutual aid in Europe and North America since 1800, New York: Routledge, 118.

Harris, B. and Hinde, A. (2019), 'Sanitary investment and the decline of urban mortality in England and Wales, 1817-1914', History of the Family, 24 (2).

Harris, J. (1972), Unemployment and politics: a study in English social policy 1886 1914, Oxford: Clarendon Press.

Harris, J. (1977), William Beveridge: a biography, Oxford: Clarendon Press.

Harris, J. (1981), 'Some aspects of social policy in Britain during the Second World War', in W.J. Mommsen, ed., The emergence of the welfare state in Britain and Germany, 1850-1950, London: Croom Helm, 247-62.

Henriques, U. (1979), Before the welfare state: social administration in early industrial Britain, London: Longman.

Humphries, S. (1981), Hooligans or rebels? An oral history of working-class childhood and youth 1889-1939, Oxford: Basil Blackwell.

Hurt, J.S. (1979), Elementary schooling and the working classes 1860-1918, London: Routledge and Kegan Paul.

Jefferys, K. (1987), 'British politics and social policy during the Second World War', Historical Journal, 30, 123-44.

Johnson, P. (1996), 'Risk, redistribution and social welfare in Britain from the Poor Law to Beveridge', in M. Danton, ed., Charity, self-interest and welfare in the English past, London: UCL Press, 225-48.

Jones, K. (1990), The making of social policy in Britain, 1830-1990, London: Athlone.

Kidd, A. (1999), State, society and the poor in nineteenth-century England, Basingstoke: Macmillan.

Levitt, I. (1988), Poverty and welfare in Scotland 1890-1948, Edinburgh: Edinburgh University Press.

Lowe, R. (1990), 'The Second World War, consensus and the foundation of the welfare state', Twentieth Century British History, 1, 152-82.

Lowe, R. (2005), The welfare state in Britain since 1945, Basingstoke: Palgrave, $3^{\text {rd }}$ edition.

Luddy, M. (1998), 'Religion, philanthropy and the state in late-eighteenth and earlynineteenth century Ireland', in H. Cunningham and J. Innes, eds., Charity, philanthropy and reform from the 1690s to 1850, Basingstoke: Macmillan, 148-67.

Macnicol, J. (1986), 'The effect of the evacuation of schoolchildren on official attitudes to state intervention', in H.L. Smith, ed., War and social change: British society in the Second World War, Manchester: Manchester University Press, 3-31.

Forthcoming in H. Bochel and G. Daly, eds., Social policy, London: Routledge, $4^{\text {th }}$ edition. 
Marshall, T.H. (1950), Citizenship and social class and other essays, Cambridge: Cambridge University Press.

McDermid, J. (2015), 'Education and society in the era of the School Boards, 18721918', in R. Anderson, M. Freeman and L. Paterson, eds., The Edinburgh history of education in Scotland, Edinburgh: Edinburgh University Press, 190-207.

Mitchison, R. (2000), The Old Poor Law in Scotland: the experience of poverty, 1574 1845, Edinburgh: Edinburgh University Press.

Ó Tuathaigh, G. (1972), Ireland before the Famine, 1798-1848, Dublin: Gill \& MacMillan.

Parliamentary Debates (1908), Parliamentary Debates, $4^{\text {th }}$ series, vol. 190.

Parliamentary Papers (1942), PP 1942-3 Cmd. 6404 vi, 119, Report by Sir William Beveridge on Social Insurance and Allied Services.

Parliamentary Papers (1943), PP 1942-3 Cmd. 6458 xi, 21, Educational reconstruction.

Parliamentary Papers (1944a), PP 1943-4 Cmd. 6527 viii, 119, Employment policy.

Parliamentary Papers (1944b), PP 1943-4 Cmd. 6502 viii, 315, Ministry of Health/Department of Health for Scotland, A national health service.

Paterson, L. (2015), 'Democracy or intellect: the Scottish educational dilemma of the twentieth century', in R. Anderson, M. Freeman and L. Paterson, eds., The Edinburgh history of education in Scotland, Edinburgh: Edinburgh University Press, 226-45.

Pelling, H. (1968), 'The working class and the origins of the welfare state', in $\mathrm{H}$. Pelling, Popular politics and society in late-Victorian Britain, London and Basingstoke: Macmillan, 1-18.

Roberts, D. (1960), Victorian origins of the British welfare state, New Haven: Yale University Press.

Roberts, E. (2000), 'The recipients' view of welfare', in J. Bornat, R. Perks, P. Thompson and J. Walmsley, eds., Oral history, health and welfare, London: Routledge, 203-26.

Rose, M. (1966), 'The anti-poor law movement in the north of England', Northern History, 1, 70-91.

Slack, P. (1995), The English Poor Law, 1531 -1782, Cambridge: Cambridge University Press.

Slack, P. (1999), From Reformation to improvement: public welfare in early-modern England, Oxford: Clarendon Press.

Szreter, S. (2002a), 'Health, class, place and politics: social capital and collective provision in Britain', Contemporary British History, 16 (3), 27-57.

Szreter, S. (2002b), 'A central role for local government? The example of lateVictorian Britain', History and Policy, Policy Paper no. 1. URL:

http://www.historyandpolicy.org/archive/pol-paper-print01.html.

Szreter, S. and Mooney, G. (1998), 'Urbanisation, mortality and the standard of living debate: new estimates of the expectation of life at birth in nineteenth-century British cities', Economic History Review, 51, 84-112.

Thane, P. (1982), The foundations of the welfare state, London: Longman's, $1^{\text {st }}$ edition.

Forthcoming in H. Bochel and G. Daly, eds., Social policy, London: Routledge, $4^{\text {th }}$ edition. 
Thane, P. (1984), 'The working class and state "welfare" in Britain 1880-1914', Historical Journal, 27, 877-900.

Thane, P. (1996), Foundations of the welfare state, London: Longman ( $2^{\text {nd }}$ edition). Titmuss, R.M. (1950), Problems of social policy, London: HMSO.

Titmuss, R.M. (1987), 'War and social policy', in B. Abel-Smith and K. Titmuss, eds., The philosophy of welfare: selected writings of Richard M. Titmuss, London: Allen and Unwin, 102-12.

Welshman, A.J. (1997), 'Evacuation and social policy during the Second World War: myth and reality', Twentieth Century British History, 9, 28-53.

Williams, K. (1981), From pauperism to poverty, London: Routledge. 